\title{
In Memorial: Professor Gavril Pasternak
}

\author{
Paul A. Sloan, MD
}

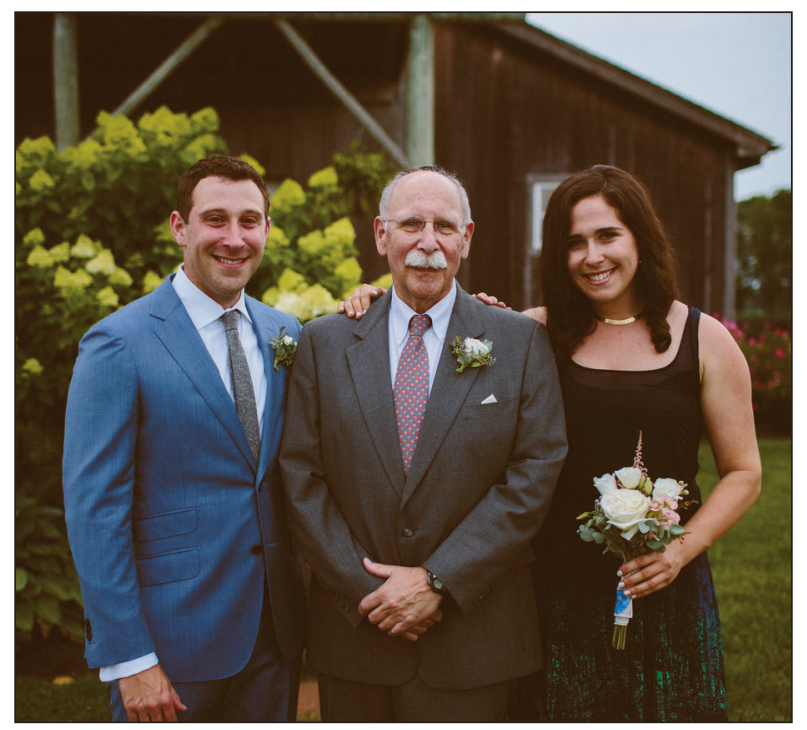

It is with sadness and compassion that I write this editorial in the memory of Professor Gavril Pasternak. The field of Science, Pain Medicine, Neurology, Pharmacology, and Opioid Science and Pharmacology lost a world leader and pioneer in all of these areas, this February 2019. On behalf of the Journal of Opioid Management, the Editorial Board, the Publisher, the International Conference on Opioids, and as Editor-in-Chief, I am honored to give tribute to the life and person of Dr. Gavril Pasternak.

To summarize the life and work of Dr. Pasternak in a few pages is not possible, but this author is pleased to try and present some important highlights. Dr. Pasternak graduated from Johns Hopkins School of Medicine, and then completed a residency in Neurology also at Hopkins. He completed Fellowship work at Johns Hopkins in the laboratory of Dr. Sol Snyder in Pharmacology and Experimental Therapeutics. Thus, Dr. Pasternak was both a true clinician and scientist, always using science to help treat patients with pain using newer and better methods.

Following post-graduate work, he joined the Memorial Sloan Kettering faculty in 1979, rising to the Anne Burnett Tandy Chair of Neurology. He also served as Laboratory Head in the Molecular Pharmacology Program with the Sloan Kettering Institute, thus mentoring dozens of graduate and post-graduate students. His more than 400 published manuscripts covered his research into opioid and opioid receptor biochemistry, genetics and pharmacology. Always the clinician, his review papers explaining opioid systems for the physician are masterful in their clarity and presentation. ${ }^{1-5}$ Dr. Pasternak's most recent review on opioid pharmacology was published just last year. ${ }^{5}$

Dr. Pasternak received numerous scientific awards from around the world that recognized his investigative and groundbreaking research. These included the American Society for Pharmacology and Experimental Therapeutics Axelrod Award, the American Academy of Neurology Weir Mitchell Award, the American Society of Pharmacology and Experimental Therapeutics Harrington ScholarInnovator Award, and the Norwegian University of Science and Technology Millennium Prize, to name a few. His most recent prestigious honor is the American Pain Society 2019 Kerr Basic Science Research Award. Dr. Pasternak served on the Editorial Boards of numerous science journals, and we were privileged to have him lecture on two 
different occasions at the annual International Conference on Opioids. His intellectual brilliance was evident in his research and lectures, yet Dr. Pasternak was always helpful to young investigators, willing to share his time and energy with other scientists. Dr. Pasternak was very approachable in person, never aloof or pretentious, and quite humble in character.

Professor Pasternak's scientific and clinical research started 46 years ago and never waivered from the need to discover what the opioid system was all about, and how increased knowledge of opioid receptors and their pharmacology could lead to analgesics that were safer and less addictive. The investigations started in 1973 while working with Professor Snyder, and the first data suggesting the existence of specific opioid receptors in the brain. ${ }^{6} \mathrm{~A}$ year later his seminal paper characterized the nature of the opiate receptor as "a membrane-bound complex whose stereospecific binding is dependent upon the integrity of both proteins and phospholipids". 7 This was a remarkable discovery that would be proven correct. Then in 1974, he presented a paper that identified, described, characterized and proposed the opiate receptor that is now so universally accepted. ${ }^{8}$ Merely one year later, 1975, perhaps the first paper to suggest and give hard data for the presence of endogenous opioid-like ligands for the newly discovered opiate receptor in the brain.?

The research of Dr. Pasternak for the next decade continued to characterize opioid receptors, endogenous opioid compounds, endogenous opioid systems, and opioid pharmacology. A few of his papers around 1983 proposed the idea that separation of opioid analgesia from respiratory depression, the bane of opioid analgesia, may be possible. ${ }^{10-12}$ With the mu opioid receptor first cloned in 1993, Dr. Pasternak with his laboratory proposed and identified more than a dozen different splice variants of the mu receptor. ${ }^{3}$ The amazing finding from his work is that each different receptor variant may have distinct and quite different pharmacological actions. The discovery of opioid compounds that could bind to the mu receptor variant 6-transmembrane domain also yielded compounds that seem to lack respiratory depression or evidence of physical dependence! $!^{13,14}$ For the first time in history, the prospect of opioid analgesia devoid of respiratory depression was a real possibility. ${ }^{15,16}$

Other research from Professor Pasternak identified the sigma receptor, revealed to be closely linked and affecting opioid analgesic effects. ${ }^{17,18} \mathrm{He}$ was always looking for compounds that would be synergistic with opioid analgesia and thus reduce harmful side effects. To this end, Dr. Pasternak studied analgesics such as tricyclic antidepressants, NMDA receptor antagonists, sigma 1 selective antagonists, nonsteroidal anti-inflammatory drugs, and co-administered opioids. ${ }^{19-23}$ He was part of a group of clinicians who suggested the individual variability in response to opioid therapy, a concept that is now widely accepted and based upon the wide genetic variability shown among humans. ${ }^{24}$ The diverse genetics shown in his laboratory gave a biochemical basis for the useful practice of opioid rotation in patients with chronic pain. ${ }^{25}$

The most recent publication in 2019 from Professor Pasternak's laboratory highlights his everlasting search, in a controlled scientific manner, for better opioid analgesics with reduced side effects. ${ }^{26}$ Patients with pain, from around the world, are grateful for a clinician-scientist who sought to relieve suffering in the most effective and safe way possible. Thank you Professor Gavril Pasternak.

In recognition of the life and work of Professor Pasternak the International Conference on Opioids (ICOO) is pleased to announce the annual Gavril Pasternak Scholarship, and the annual Gavril Pasternak Keynote Presentation at 2019 ICOO Annual Meeting.

Finally, the Journal of Opioid Management, the Publisher, the Editorial Board and the Editor-inChief would like to pass on the family and close friends of Professor Pasternak our deepest sympathies and condolences. Thank you family for sharing Dr. Pasternak with us; we are all better for having known his gentle spirit and the entire world has benefitted from his scientific discoveries.

Paul A. Sloan, MD, Editor-in-Chief, Journal of Opioid Management, Professor of Anesthesiology, University of Kentucky, Lexington, Kentucky.

\section{GAVRIL PASTERNAK MEMORIAL EDUCATION FUND}

Available at: https://www.gofundme.com/gavrilpasternak-memorial-education-fund-icoo

The goal of this go fund me page is to raise funds in the name of Dr. Gavril Pasternak to provide scholarship to allow students and/or healthcare professionals to attend and learn at the International Conference On Opioids and/or the International Narcotics Research Conference. 


\section{REFERENCES}

1. Pasternak GW, Pan YX: Mix and match: Heterodimers and opioid tolerance. Neuron. 2011; 69(1): 6-8.

2. Pasternak GW: Preclinical pharmacology and opioid combinations. Pain Med. 2012 Mar; Suppl 1: S4-11.

3. Pasternak GW: Opioids and their receptors: Are we there yet? Neuropharmacology. 2014; 76: 198-203.

4. Pasternak GW: Opiate pharmacology and relief of pain. JClin Oncol. 2014; 32(16):1655-1561.

5. Pasternak GW: Mu opioid pharmacology: 40 years to the Promised Land. Adv Pharmacol. 2018; 82: 261-291.

6. Pert CB, Pasternak GW, Snyder SH: Opiate agonists and antagonists discriminated by receptor binding in brain. Science. 1973; 182: 1359-1361.

7. Pasternak GW, Snyder SH: Opiate receptor binding: Effects of enzymatic treatments. Mol Pharmacol. 1974; 10(2): 183-193.

8. Snyder SH, Pert CB, Pasternak GW: The opiate receptor. Ann Intern Med. 1974; 81(4): 534-540.

9. Pasternak GW, Goodman R, Snyder SH: An endogenous morphine-like factor in mammalian brain. Life Sci. 1975; 16(12): 1765-1769.

10. Ling GS, Spiegel K, Nishimura SL, Pasternak GW: Dissociation of morphine's analgesic and respiratory depressant actions. Eur J Pharmacol. 1983; 86(3-4): 487-488.

11. Ling GS, MacLeod JM, Lee S, et al.: Separation of morphine analgesia from physical dependence. Science. 1984; 226(4673): 462-464.

12. Ling GS, Spiegel K, Lockhart SH, Pasternak GW: Separation of opioid analgesia from respiratory depression: Evidence for different receptor mechanisms. J Pharmacol Exp Ther. 1985; 232(1): 149-155.

13. Majumdar S, Grinnell S, Le Rouzic V, et al.: Truncated G protein-coupled mu opioid receptor MOR-1 splice variants are targets for highly potent opioid analgesics lacking side effects. Proc Natl Acad Sci. USA. 2011; 108: 19776-19783.

14. Lu Z, Xu J, Rossi GC, et al.: Mediation of opioid analgesia by a truncated 6-transmembrane GPCR. J Clin Invest. 2015; 215(7): 2626-2630.
15. Grinnell SG, Majumdar S, Narayan A, et al.: Pharmacologic characterization in the rat of a potent analgesic lacking respiratory depression, IBNtxA. J Pharmacol Exp Ther. 2014; 350(3): 710-718.

16. Lu Z, Xu J, Xu M, et al.: Truncated $\mu$-opioid receptors with 6 transmembrane domains are essential for opioid analgesia. Anesth Analg. 2018; 126(3): 1050-1057.

17. Pasternak GW, Carroll-Buatti M, Spiegel K: The binding and analgesic properties of a sigma opiate, SKF 10,047. J Pharmacol Exp Ther. 1981; 219(1): 192-198

18. Chien CC, Pasternak GW: Sigma antagonists potentiate opioid analgesia in rats. Neurosci Lett. 1995; 190(2): 137-139.

19. Spiegel K, Kalb R, Pasternak GW: Analgesic activity of tricyclic antidepressants. Ann Neurol. 1983; 13(4): 462-465.

20. Elliott K, Minami N, Kolesnikov YA, et al.: The NMDA receptor antagonists, LY274614 and MK-801, and the nitric oxide synthase inhibitor, NG-nitro-L-arginine, attenuate analgesic tolerance to the mu-opioid morphine but not to kappa opioids. Pain. 1994; 56(1): 69-75.

21. Kim FJ, Kovalyshyn I, Burgman M, et al.: Sigma 1 receptor modulation of G-protein-coupled receptor signaling: Potentiation of opioid transduction independent from receptor binding. Mol Pharmacol. 2010; 77(4): 695-703.

22. Zelcer S, Kolesnikov Y, Kovalyshyn I, et al.: Selective potentiation of opioid analgesia by nonsteroidal anti-inflammatory drugs. Brain Res. 2005; 1040(1-2): 151-156.

23. Bolan EA, Tallarida RJ, Pasternak GW: Synergy between mu opioid ligands: Evidence for functional interactions among mu opioid receptor subtypes. J Pharmacol Exp Ther. 2002; 303(2): 557-562.

24. Galer BS, Coyle N, Pasternak GW, et al.: Individual variability in the response to different opioids: Report of five cases. Pain. 1992; 49(1): 87-91.

25. Jeevendra Martyn JA, Mao J, Bittner EA: Opioid tolerance in critical illness. NEngl J Med. 2019; 380: 365-378.

26. Atigari DV, Uprety R, Pasternak GW, et al.: MP1104, a mixed kappa-delta opioid receptor agonist has anti-cocaine properties with reduced side-effects in rats. Neuropharmacology. 2019; Feb 13. Pii: S0028-3908. (Epub ahead of print) 